UDC 364.05: 336

DOI 10.35433/ISSN2410-3748-2019-2(25)-8

Poita Iryna

Ph.D., Docent Department of Economics,

Management and Marketing

Kalinichenko Olena

Ph.D., Senior Lecturer Department

of Economics, Management and Marketing

Zhytomyr Ivan Franko State University

Ukraine

\title{
FOREIGN EXPERIENCE OF SOCIO-ECONOMIC REINTEGRATION OF DEMOBILIZED WAR VETERAN AND ITS POSSIBLE IMPLEMENTATION IN UKRAINE
}

\begin{abstract}
Article is made for analysis leading foreign experience and develop training and educational measures aimed at shaping the economic behavior of demobilized participants and ATO veterans, acquiring them new financial and entrepreneurial competences; study, development, testing and implementation of training programs and workshops. The article is aimed at increasing the degree of socio-economic adaptation, the level of economic literacy and the development of entrepreneurial initiatives to start its own business for demobilized participants and veterans of the Zhytomyr anti-terrorist operation veterans, who left the Armed Forces of Ukraine and return to civilian life. Measures of socio-economic adaptation of military personnel involved in long-term military conflicts and sources for financing of relevant measures by both the state and business are proposed. Business can count on information-consulting support, but it can to be effective in the case of coordinated and concerted action at both national and regional levels, attracting such support from business representatives under public-private partnerships. The article investigates the formation of

financial competences of demobilized participants and ATO veterans, reveals the main problems of lack of financial and economic knowledge and the consequences of their failure.

The study in the field of socio-economic adaptation of demobilized combatants in the ATO area have identified the urgency of the problem of systematic implementation of scientific and methodological and practical programs, development and support of entrepreneurial initiatives for the creation and conduct of private (family) business. Starting a business by demobilized ATO participants and veterans is an important tool for their socioeconomic adaptation. In the process of setting up and running a business, they face problems that are specific to other categories of entrepreneurs. Therefore, consistent implementation of a well-balanced and comprehensive program for the development of small and medium-sized enterprises at both national and regional levels is an important prerequisite for promoting the entrepreneurial initiatives of demobilized participants and veterans of the ATO.
\end{abstract}

(C) Poita I., Kalinichenko O. 
Keywords: anti-terrorist operation, ATO participants, ATO veterans, socio-economic adaptation; business planning, government program; entrepreneurship.

\section{ЗАКОРДОННИЙ ДОСВІД СОЦІАЛЬНО-ЕКОНОМІЧНОЇ АДАПТАЦІЯ ДЕМОБІЛІЗОВАНИХ УЧАСНИКІВ І ВЕТЕРАНІВ ВІЙНИ ТА МОЖЛИВОСТІ ЙОГО ВПРОВАДЖЕННЯ В УКРАЇНІ}

Стаття пересвячена аналізу провідного закордонного досвіду та розробичі навчальних та просвітницьких заходів з метою формування економічної поведінки демобілізованих учасників та ветеранів АТО, набуття ними нових фінансових, підприємницьких компетенцій; вивчення, розробки, апробації та впровадження програми тренінгів та воркшопів. Стаття спрямована на підвищення ступеня соціально-економічної адаптації, рівня економічної грамотності та розвиток підприємниџьких ініціатив щзодо відкриття власного бізнесу демобілізованим учасникам та ветеранам АТО Житомирщини, які покинули лави Збройних сил Украйни $і$ повертаються до ичивільного життя. Запропоновано заходи соиіально-економічної

адаптації військовослужбовців, які брали участь у бойових конфліктах у довгостроковій перспективі, та джерел для фінансування відповідних заходів як з боку держави, так $i$ з боку бізнесу.. 3 боку бізнесу можна розраховувати на інформаційноконсультаційну підтримку, але вона може бути дієвою за умови скоординованих та узгоджених дій як на начіональному, так і на регіональному рівнях, залучення до такої підтримки представників бізнесу на умовах державно-приватного партнерства.

У статті досліджено формування фінансових компетенцій демобілізованих учасників та ветеринав АТО, розкрито основні проблеми відсутності фінансовоекономічних знань та наслідки їх не вирішення. Обтрунтовано дослідження у сфері сочіально-економічної адаптації демобілізованих учасників бойових дій в зоні АТО визначили актуальність проблеми системного впровадження науково-методччних та практичних програм, розвитку та підтримки підприємницьких ініціатив щуодо створення та ведення приватного (сімейного) бізнесу. Створення власного бізнесу демобілізованими учасниками та ветеранами АТО є важливим інструментом їх соціально- економічної адаптаџіï. У процесі заснування та ведення бізнесу вони стикаються з проблемами, які характерні для інших категорій підприємиів. Тому послідовне впровадження виваженої та комплексної програми розвитку малого та середнього підприємництва як на національному, так $і$ на регіональному рівнях $\epsilon$ важливою передумовою сприяння підприємницьким ініціативам демобілізованих учасників та ветеранів АТО.

Ключові слова: антитерористична операџія, учасники АТО, ветерани АТО, соціально-економічна адаптація; бізнес-планування, державна програма; підприємництво.

\section{Formulation of the problem in general form and its relation to} important scientific or practical tasks. Given the continued Russian aggression in eastern Ukraine, the number of veterans, war disabled and combatants participating in the anti-terrorist operation is increasing. Zhytomyr region is one of the most active participants in the confrontation due to the 
location of a large number of military sites in the region. Having returned to civilian life, demobilized participants may not always return to their previous jobs, finding it difficult to adapt, and cannot find their path in today's society. Therefore, there is a need for psychological, social and economic-regional adaptation, for which a number of state, municipal, social and volunteer organizations have been created. However, the economic socialization of demobilized ATO participants remains low, due to a number of problems:

- lack of awareness and lack of knowledge about the conditions for setting up and running a business;

- knowledge of the rights and responsibilities of consumers of financial services;

- ignorance of financial risks and management,

- inability to manage their own funds; ignorance of the rules of social entrepreneurship and lack of awareness of state programs supporting veterans of ATO [2].

The object of the research is the process of increasing the level of economic literacy of demobilized participants and veterans of the Zhytomyr anti-terrorist operation and promoting the development of their entrepreneurial initiatives.

The subject of the study is the theoretical and methodological foundations of socio-economic adaptation of demobilized participants and veterans of the ATO of Zhytomyr region.

Analysis of recent research and publications that address this issue. The issue of adaptation of demobilized ATO participants and veterans is now the subject of debate by many scholars and practitioners. A significant contribution to the study of theoretical and practical aspects of increasing the level of socio-economic adaptation in Ukraine was investigated by such scientists as: E. Angel, V. Antonyuk, I. Goncharenko, V. Gorbulin, M. Zakirov, 
K. Ivashchenko, O. Krasovskaya, O. Kutsenko, E. Libanova, S. Pyrozhkov, L. Ptashchenko, etc.

Socio-economic adaptation has become the object of active scientific research by foreign scientists N. Armstrong, N. Boldon, S. Gosselin, R. Mori, O. Nifatova, who pay attention to the formation of entrepreneurial skills in combatants of developed countries; In the works of M. Kuznetsov, M. Ovchinnikov, L. Stakhovich, A. Stolyarova, G. Shakhnazaryan the relationship between the level of economic literacy and activity of investment activity is covered, the necessity of formation of financial planning skills is determined and ways of increasing the entrepreneurial literacy of the population are considered.

However, there is no comprehensive analysis and program of socioeconomic adaptation of demobilized ATO participants and veterans in the Zhytomyr region. Such a program should demonstrate, in a training and business form, basic knowledge about starting a business, the dynamics of economic literacy, which will allow the demobilized participants and veterans of the antiterrorist operation of the Zhytomyr region to adapt, integrate into the modern context of entrepreneurial activity, increase the desire for the development of private entrepreneurship, creativity and the development of small and mediumsized businesses in the region.

Formulating the goals of the article. Absence of key competences of economic behavior in the field of entrepreneurial activity related to the idea of development technologies, lending and insurance, secure investing, tax discipline, adequate assessment of financial risks, leads to the fact that the number of uninformed consumers and investors, as well as unreliable credit representatives of the younger generation.

The urgency and expediency of carrying out the tasks of the study is conditioned by: 
- imperfect legal framework for the protection of the rights of participants and veterans of the ATO;

- the lack of effective mechanisms to protect the rights of future entrepreneurs in combination with the low level of financial literacy of the population of Ukraine;

- inability to manage their own and family finances and identify fraudulent "quick enrichment" schemes or other financial pyramids;

- ignorance in the field of business fundamentals, business planning fundamentals and mechanisms of managing one's business;

- lack of information on the possibility of receiving one-off assistance for the organization of business activities;

- the need to implement the progressive experience of countries that have participated in military conflicts, and therefore have effective tools in place for socio-economic support for demobilized participants, veterans, including through promoting their entrepreneurial initiatives [5].

The theoretical and methodological basis for the study of socio-economic adaptation is determined by system-structural, situational and functional approaches.

\section{Outline of the main research material with full justification of} scientific results. Socio-economic adaptation can take the following forms:

1. Traditional employment, that is, return to the previous place of employment or work for hire elsewhere. This right in Ukraine is guaranteed to the participants of the ATO in the legislative order, in particular Article 119 of the Labor Code of Ukraine guarantees the right to save a job during the mobilization.

2. Social entrepreneurship, by which we mean systematic (including innovation and economic activity) that involves overcoming social problems. In particular, social entrepreneurship is an activity whose results are aimed at a particular social group or solving certain problems. 
3. Starting your own business. In their inclination and ability to do their own thing, the former military is not fundamentally different from the rest of the country's population: the percentage of successful businesses created by military veterans is almost indistinguishable from that of rest of the populations. At the same time, own business offers good opportunities for self-realization and independence, which can also be considered as an element of social and psychological adaptation [4].

In the practice of developed leading countries, programs that stimulate the opening of their own business for veterans or training for it are quite relevant.

Extremely relevant and effective is the experience of working with demobilized participants and veterans of the US war.

In August 2017, there were approximately 20.5 million veterans in the United States, with nearly $75 \%$ of veterans serving in military conflicts. About $50 \%$ of veterans belong to the working population $(6.4 \%$ of the total working population of the country). Therefore, the problem of their socio-economic adaptation, in particular through the creation and running of their own businesses in the US, is an important issue in returning to civilian life. At the same time, about $12 \%$ of the total number of American veterans already have their own business. Also, $10.3 \%$ of all business owners were demobilized servicemen, which significantly increases the proportion of veterans among the able-bodied population. As a result, veterans' own business plays a significant role in the US economy [1].

In addition, in 2015, 442,000 veteran-owned businesses had hired employees and created more than 5 million jobs. In the current context, a number of ministries and federal agencies are addressing the socio-economic problems of veterans in the United States. Formerly serving the needs of former military personnel, the U.S. Department of Veterans Affairs has a budget of about 180 billion USD and 380,000 personnel. This authority coordinates its activities with the Department of Defense and the US Department of Health and 
Human Services. At the same time, within the framework of conducting separate directions of the policy of support of veterans. Responsibility for the development of veterans' small business is vested in the appropriate unit of the US Small Business Administration (AMB), the Office of Veterans Business Development (OVRD). The above-mentioned structural authority is responsible for maximizing the accessibility and usefulness of all AMB programs aimed at supporting veterans, members of the military reserve, and family members of the specified categories of servicemen [4].

Supporting the creation of a veterans' own business is done through a number of educational and financial tools. First and foremost, it is about implementing a "From Army Boots to Business" program that allows veterans, military, and their families to gain a basic knowledge of doing business. The program is based on public-private partnerships and brings together AMB, the US Department of Defense, Syracuse University and a range of community partners.

The program consists of three main elements:

- An introductory information video, an optional two-day Entry to Entrepreneurship course, and an online Entrepreneurship Basics course. A consortium of universities, led by the Institute for Veterans and Military Families (IVMF), is working on the preparation and development of training materials.

- Supported by the Veterans Business Development Office throughout the country, there are Veterans Business Support Centers that organize professional training, help create business plans, and provide mentoring support.

- Entrepreneurship education initiatives are also supported by the US Department of Veterans Affairs, which pays for the training courses offered by the Small Business Development Center (SBDC) on business plans, export and import support, market analysis assistance, and more [5]. 
Both veterans planning to start their own businesses and veterans who are already business owners can take advantage of these opportunities, as well as the opportunity to retake higher level courses [2].

Government support for veterans and their families also provides a number of financial instruments for starting their own businesses. In particular, AMB offers a selection of veteran lending programs. Banks and other lending institutions work with AMB to provide loans for small business veterans to start and grow their businesses. To this end, the Veterans Advantage Guaranteed Loan Program is in place. AMB provides guarantees ranging from $50 \%$ to $85 \%$ of the total loan amount. Veteran-owned businesses (with $51 \%$ or more) can make money. Veteran status can be used to obtain the status of a veteran and receive the appropriate rights and guarantees from the program:

- veterans released into stock (not by a court order for serious crimes);

- veterans with disabilities;

- those who still serve in the military and participate in the Transition Assistance Program aimed at preparing military personnel for civilian life;

- reservists and servicemen of the National Guard;

- the wife (husband) of all the above categories of citizens, the widow (s) of the deceased in the service.

Entrepreneurship education initiatives are also supported by the US Department of Veterans Affairs, which pays for training courses offered by the Small Business Development Center (SBDC) on business plans, export and import support, market analysis assistance, etc. [3]. Under US law, military retirees have substantial tax benefits. All payments received by retirees from the Department of Veterans Affairs are exempt from income tax. These benefits include: educational assistance, training, grants, food payments and disability pensions.

Equally significant and effective programs are in place in the UK and some Commonwealth countries (eg Canada). Socio-economic assistance to war 
veterans is provided by nonprofit government-funded non-profit organizations and charities. In particular, the Royal British Legion, which was created in 1921 by veterans of the First World War, is active in Britain. The main task of the organization is to solve the problems of veterans, who could not cope with the government. Every citizen can become a member of the British Legion. The Royal British Legion implements the Civvy Street program, which aims to facilitate the employment of civilians (both veterans and those who will soon be discharged). The same measures apply to widows, widowers, partners and dependents [5].

Since self-employment is one way to solve the problem of employment, Legion provides a number of services to help you start a business:

- trainings to start your own business;

- assistance in writing business plans;

- financial planning assistance;

- assistance in finding funding sources;

- business health check, mentoring.

Canada has a unique veterans 'support program for Veterans' Operation Prince's Operation Entrepreneur, started by Prince Charles's Charities Canada, a student volunteer organization (Enactus Memorial) and a non-profit organization, Futurpreneur, to help create and operate businesses young people.

The program is funded and supported by the Government of Canada, financial institutions and charities. The "Entrepreneur" program provides sevenday basic training for entrepreneurship, as well as one-day seminars.

As a result of an analysis of the experience of the United States, the United Kingdom and Canada, we can conclude that there is a need to envisage special programs for promoting self-employment for veterans. In particular, when developing a system of socio-economic adaptation of veterans, it is important to take into account the following features of adaptation of military personnel: 
- conducting educational activities for the military about the possibilities of entrepreneurial activity during the service stage, in particular on the eve of demobilization. For example, online courses and multi-day in-service military training are provided in the US;

- such experience of rehabilitation of veterans is a good example of synergy of the state, society and business aimed at solving urgent socioeconomic problems;

- Veterans' entrepreneurial incentive programs also guarantee equal rights for ex-servicemen with disabilities. Such international experience is an important empirical basis for the development and successful implementation of similar programs of socio-economic adaptation of ATO participants in Ukraine [2].

Since the beginning of the anti-terrorist operation in Ukraine, the government has adopted a large number of legal acts regulating various aspects of social and psychological adaptation of ATO veterans. These programs envisage:

- preserving the place of work for the mobilized persons;

- priority allocation of land for ATO veterans;

- compulsory psychological rehabilitation, etc.

At the same time, no national legislation has yet been adopted at the national level to directly facilitate the socio-economic adaptation of demobilized ATO participants, veterans and people with disabilities. At the same time, the Ukrainian State Employment Service takes measures to support entrepreneurial activity, which is one of the ways of social and economic adaptation of ATO veterans. At the regional level, there are already examples of the development and implementation of strategic documents aimed at developing entrepreneurial initiatives of ATO veterans.

The most successful example in Ukraine is the experience of the Ternopil region, where in 2016 the Strategy for development of small and medium-sized 
entrepreneurship of the Ternopil region for the period up to 2020 was adopted and successfully implemented, one of the objectives of which is formulated as "Involvement of ATO participants and internally displaced persons in entrepreneurship". Strategic documents on the development of small and medium-sized enterprises for ATO participants are also being developed by public sector experts. In particular, the winners of the Road Map Competition in Ternopil and Kyiv regions are preparing Roadmaps for the development of business initiatives of ATO veterans. The competition was run by the Institute for Economic Research and Policy Consulting under the USAID Leadership in Economic Governance Program. The Roadmap is a set of interconnected steps, steps and activities designed to rationally combine the efforts of the public, government, business and ATO veterans to mobilize the region's resources and maximize the consideration of the interests of all stakeholders in order to create favorable conditions for small and medium-sized enterprises. It is planned that in the Kyiv region the Roadmap will be approved as an independent policy document and in the Ternopil region its activities will be integrated into the regional SME development program. As a result, the implementation of the Roadmap measures will contribute to solving the problem of socio-economic adaptation of ATO veterans by implementing their entrepreneurial initiatives and creating conditions for better informing ATO participants about the activities and plans of the city authorities regarding the development of entrepreneurship in the region and establishing an active dialogue between the authorities and ATO veterans to open and develop their own business. More information on the development and implementation of Roadmaps can be found on the official USAID LEV33 website.

The novelty of the work is as follows:

- theoretically substantiated methodology of training of business planning process, basics of business activity, financial literacy for demobilized participants and veterans of anti-terrorist operation of Zhytomyr region, which 
provides applied and professional orientation of training, formation of economic competences in them, including readiness and financial activities;

- the scientific bases of formation of organizational and economic mechanism of perspective development of medium and small business among demobilized participants of hostilities, as a component of the process of economic socialization;

- outlines the prospects of forming economic socialization in the light of European experience.

Conclusions and prospects for further research. Thus, the socioeconomic adaptation of military personnel and veterans of combat operations and the search for effective ways of its realization occupy one of the central places among the scientific problems investigated by domestic and foreign authors today. Restoration of working capacity, improvement of financial status and psychological health of veterans is a priority today. Being able to start your own business can be one of the effective tools to help combat veterans. Psychologists point out that they have great potential for successful business management because they have the ability to respond more quickly to changed circumstances and have a greater willingness to take risks. Accordingly, they are more open to innovation in business than people without such experience. Ukrainian enterprises can actively support the support of war veterans participants of hostilities in entrepreneurial initiatives, implementing the principle.

The current state of state aid to demobilized participants and veterans of the ATO is unsatisfactory, since most of the measures are only legally stipulated, but, in fact, they are not accessible. Since the beginning of 2015, a significant number of legislative acts have been adopted on the various forms of rehabilitation of ATO participants - each of them has stated what needs to be done, but none has specified in what way. One source of funding could be a military levy. But for this purpose it is necessary to transfer this fee to the 
special fund of the state budget, indicating the directions of its use, which can be controlled. The proposals provided are an important way of socio-economic adaptation of demobilized ATO participants and veterans, as well as the military as a whole.

The conducted research is of theoretical and practical importance, it can be used in the process of development and implementation of the concept of development of small and medium business in Ukraine by raising the economic, financial and entrepreneurial consciousness of the respective categories of citizens. The expected results will be valuable in determining the strategic foundations of state support and tactical approaches to its implementation, in the activities of public authorities and public administration related to the improvement of the current legislation in the context of improving the efficiency of economic development, the system of social protection of the population and the reform of the domestic remuneration system. and income taxation of individuals.

The results obtained during the implementation of the project can be used by the State Service of Ukraine for War Veterans Affairs and participants of the anti-terrorist operation to implement programs related to the socio-economic adaptation of veterans (to date, there is no profile unit in the structure of the Office). Territorial branches of the Civil Service can direct ATO participants to structures that will provide professional advice on starting and running their own business, such as the State Employment Service of Ukraine, specialized volunteer organizations that care about socio-economic adaptation of veterans, and have educational programs and professionals. In addition, this program will be of interest to veterans and war veterans unions in order to adapt the vulnerable to civilian life by raising their awareness of financial and economic literacy and entrepreneurship.

\section{REFERENCES}


1. Honcharenko, I. M. (2018). Metodychni pidkhody shchodo adaptatsii uchasnykiv ATO, VPO v systemi pidpryiemnytskoi diialnosti [Methodical Approaches to Adaptation of ATO, IDP Participants in the Entrepreneurship System]. - Visnyk Kyivskoho natsionalnoho universytetu tekhnolohii ta dyzainu. Seriia Ekonomichni nauky. Kyiv [in Ukrainian].

2. Libanova, E. M. (2015). Polityka intehratsii ukrainskoho suspilstva v konteksti vyklykiv ta zahroz podii na Donbasi [Policy of integration of Ukrainian society in the context of challenges and threats of events in the Donbass] - Kyiv: NAN Ukrainy [in Ukrainian].

3. Horbulina, V. P. (2017). Svitova hibrydna viina: ukrainskyi front [World Hybrid War: Ukrainian Front. - monohrafiia. - Kyiv: NISD [in Ukrainian].

4. Ptashchenko, L. O. (2016). Pidvyshchennia rivnia finansovoi hramotnosti naselennia: mizhnarodnyi dosvid [Increasing the level of financial literacy of the population: international experience]. - Ekonomika i rehion. Kyiv [in Ukrainian].

5. Svynchuk, A.A. (2017). Sotsialne pidpryiemnytstvo: vid idei do suspilnykh zmin [Social entrepreneurship: from idea to social change]: Posibnyk. - K: TOV «IDPRYIeMSTVO «VI EN EI». Retrieved from: http://eef.org.ua/wp- content/uploads/2016/12/Book_sotsialne- pidpryyemnytst vo_pidruchnyk.pdf [in Ukrainian]. 